\title{
CORPORATE SOCIAL RESPONSIBILITY V. BUSINESS \& HUMAN RIGHTS: MAKING A PORTRAIT OF A SOCIALLY RESPONSIBLE BUSINESSMAN
}

\section{Poiedynok V. V.}

\section{INTRODUCTION}

Famous are the words of Milton Friedman that "few trends could so thoroughly undermine the very foundations of our free society as the acceptance by corporate officials of a social responsibility other than to make as much money for their stockholders as possible" Nevertheless, in the modern world most accept that business, while focused on making profit, should also be socially responsible. There two sides of the coin: on one side, companies should be conscious of the kind of impact they are having on all aspects of society including economic, social, and environmental (positive responsibility), on the other side, they should also be held accountable for the harm inflicted (negative responsibility).

Corporate Social Responsibility (CSR) and Business and Human Rights (BHR) are closely related global courses of legal academic thought focused on companies engaging in responsible and socially beneficial activities. Still, both concepts have considerable differences and hence distinct profiles that roughly correspond to the abovementioned sides of the coin.

Historically, CSR has focused on corporate voluntarism and expectations of corporations as so-called "corporate citizens" with responsibilities arising from their role as social partners ${ }^{2}$. Companies are encouraged to engage in activities ranging from corporate philanthropy to the provision of aid in case of governmental failure, because it is good for business. Generally, CSR emphasizes self-guided decision making P. 133.

${ }^{1}$ Friedman M. Capitalism and freedom. Chicago: University of Chicago Press, 1962,

2 Carroll Archie B. Corporate social responsibility: Evolution of a definitional construct. Business \& Society. 1999. № 38(3). Pp. 268-295. 
rather than the imposition of legally binding requirements and voluntary measures rather than state-sponsored regulation ${ }^{3}$.

By contrast, BHR, grows out of a quest for corporate accountability to mitigate or prevent the adverse impacts of business activity on individuals and communities and out of expectations grounded in a specific core set of human rights obligations. BHR has, at times, focused more narrowly on holding corporations accountable for harm caused rather than on a positive recognition of the role business might play in protecting and promoting human rights ${ }^{4}$.

In particular, BHR calls companies, states, and civil societies for measuring corporate conduct against universally recognized human rights principles embodied in a key set of treaties ${ }^{5}$. Essentially, BHR focuses on victims or impacted communities and articulates their concerns in terms of treaty-based human rights.

To some extent, BHR is a response to CSR and the potential failure of the latter being a vague and weak concept. This leads to the fact that both concepts are contrasted to each other by their supporters rather than productively interacting.

Both concepts are global in their expansion and intensive in their development, in particular, both in the United States and in the EU. It would be largely unfair to say that they are unknown in Ukraine. The legal issues of CSR have been comprehensively dealt with in the works of Iryna V. Lukach ${ }^{6,7}$. Since 2008, the expert organization -Center for the Development of Corporate Social Responsibility (CSR Center) has been active $^{8}$. In 2017 the Center for Policy Studies of Business \& Human Rights was created under the aegis of the Economic and Legal Studies

${ }^{3}$ Buhmann, K. Corporate social responsibility: What role for law? Some aspects of law and CSR. Corporate Governance. 2006. № 6(2). Pp. 188-20.

${ }^{4}$ Bilchitz D. The Ruggie Framework: An Adequate Rubric for Corporate Human Rights Obligations? 2009. URL: http://papers.ssrn.com/sol3/papers.cfm?abstract id=1394367 (accessed 01.06.2019).

5 International Council on Human Rights Policy (ICHRP). Beyond Voluntarism: Human Rights and the Developing International Legal Obligations of Companies. Geneva: ICHRP, 2002. URL: http://ssrn.com/abstract=1553201 (accessed 01.06.2019).

6 Лукач I.B. Теоретичні проблеми правового регулювання корпоративних відносин в Україні : монографія. К.: Ліра-К, 2015. С. 78-100.

7 Лукач I.В. Законодавче закріплення нефінансового звіту в контексті Угоди про асоціацію. Право України. 2018. № 6. С. 143-153.

8 Corporate social responsibility - CSR-UA URL: http://sr-ua.info/csr-ukraine (accessed 01.06.2019). 
Institute of the National Academy of Sciences of Ukraine. In 2018 the Institute and the Business \& Human Rights Resource Center, based in UK, signed a Memorandum of Understanding and started a Joint academic and applied project "Advancing Business and Human Rights Framework: Drivers for Ukraine" 9 . Still, it is clear that the concepts in question are not deeply rooted in Ukrainian legal thinking and are perceived as foreign. Academic papers focused on comparative discussion of the concepts and their relevance for Ukrainian legal doctrine, are non-existent in Ukraine.

The article aims to study the concepts of "Corporate Social Responsibility" and "Business \& human rights", and, in particular, to identify their common and distinctive features. I also seek to outline the perspective ways of their integration and to highlight their importance for the national legal doctrine in Ukraine.

\section{Csr: Bottom-Top}

Corporate social responsibility (CSR, also called corporate sustainability, sustainable business, corporate conscience, corporate citizenship, conscious capitalism, or responsible business) is a type of international private business self-regulation. While on its earlier stages it was possible to describe CSR as an internal organizational policy or a corporate ethic strategy, that time has passed as various international laws have been developed and various organizations have used their authority to push it beyond individual or even industry-wide initiatives ${ }^{10}$.

Historically, CSR grew out of analysis of the role of the private sector in the aftermath of World War II. In 1949, Donald K. David, Dean of the Harvard Business School, wrote an article entitled "Business Responsibilities in an Uncertain World"11. Shortly afterwards, Bernard Dempsey published the "Roots of Business

9 В Інституті економіко-правових досліджень НАН України відбувся міжнародний науково-практичний семінар «Зміцнення засад у сфері бізнесу і прав людини: драйвери для України» URL: http://www.nas.gov.ua/EN/Messages/News/ Pages/View.aspx?MessageID=4408 (accessed 01.06.2019).

${ }^{10}$ Corporate social responsibility: From Wikipedia, the free encyclopedia URL: https://en.wikipedia.org/wiki/Corporate_social_responsibility (accessed 01.06.2019).

11 David D. Business Responsibilities in an Uncertain World. Harvard Business Review. 1949. № 27 (3 Suppl.). Pp. 1-8. 
Responsibility" in the Harvard Business Review ${ }^{12}$. In both of these articles, the authors called upon business to contribute to the wellbeing and progress of individuals and society. Business had an obligation to create a just society beyond the boundaries of the business entity. Another key scholar Morell Heald highlighted corporate philanthropy as the earliest form of CSR as well as cooperation and leadership on a range of community issues ${ }^{13}$.

In 1953 Howard Bowen published the landmark book "Social Responsibilities of the Businessmen", discussing the concept of businessmen and their obligation to pursue objectives desirable for society. Bowen set forth an initial definition of the social responsibilities of businessmen: "It refers to the obligations of businessmen to pursue those policies, to make those decisions, or to follow those lines of action which are desirable in terms of the objectives and values of our society" ${ }^{14}$. He is credited by many as the father of CSR and the book marks the beginnings of the modern period of literature on this subject.

Patrick Murphy differentiates between four "CSR eras": the "philanthropic" era (the period up to the 1950s), in which companies donated to charities more than anything else; the "awareness" era (1953-67), in which there became more recognition of the overall responsibility of business and its involvement in community affairs; the "issue" era (1968-73), in which companies began focusing on specific issues such as urban decay, racial discrimination, and pollution problems; the "responsiveness" era (1974-8 and continuing beyond), in which companies began taking serious management and organizational actions to address CSR issues, including altering boards of directors, examining corporate ethics, and using social performance disclosures ${ }^{15}$.

12 Dempsey B. The Roots of Business Responsibility. Harvard Business Review. 1949. № 27 (4). Pp. 393-404.

${ }^{13}$ Heald M. The Social Responsibilities of Business: Company and Community 1900-1960. Livingston : Transaction Publishers, 1970. Pp. 118-119.

${ }^{14}$ Bowen H. Social Responsibilities of the Businessman. Iowa City: University of Iowa Press, 1959/2013, p. 6.

15 History of Corporate Responsibility Project. Corporate social responsibility: The shape of a history, 1945-2004 : Center for Ethical Cultures Working Paper, 2005. Pp. 24-25. URL: http://www.cebcglobal.org/index.php?/knowledge/history-workingpapers/ (accessed 01.06.2019). 
Still, CSR lacks common definition. According to Andreas Georg Scherer \& Guido Palazzo, the bordering concepts are business and society, business ethics, and stakeholder theory ${ }^{16}$.

CSR academics have debated what obligations do fall within CSR whether it is enough for companies to comply with general legal and economic obligations (complying with law) or whether CSR represents an additional layer of obligations beyond mere compliance. In my view, Keith Davis is to be sited here: "For purposes of this discussion it [CSR] refers to the firm's consideration of, and response to, issues beyond the narrow economic, technical, and legal requirements of the firm. It means that social responsibility begins where the law ends. A firm is not being socially responsible if it merely complies with the minimum requirements of the law, because this is what any good citizen would do" $" 17$. I strongly support the latter point: mere compliance with law does not require special names, and under normal conditions of the rule of law is a routine, not a best practice worth lauding. But anyway, the emphasis in the CSR discourse is more on a corporate responsibility and responsiveness rather than on state-driven regulation or accountability ${ }^{18}$.

Approaches to CSR vary also geographically. As Iryna V. Lukach points out, the American trend in introducing CSR is characterized by a more voluntary approach; in this, the load of implementing CSR is borne by the public and is based on the social awareness of citizens and corporations alike. For Europe, enhancing the governmental regulation of CSR standards is more characteristic and is based on CSR reporting and accountability ${ }^{19}$.

The European Commission defines CSR as "the responsibility of

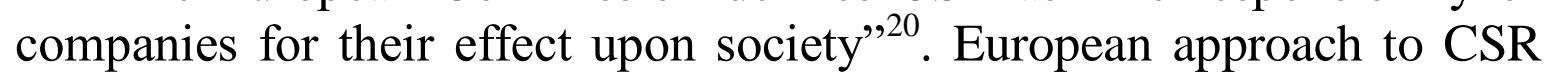

${ }^{16}$ Scherer A., Palazzo G. Toward a Political Conception of Corporate Responsibility: Business and Society Seen from a Habermasian Perspective. Academy of Management Review. 2007. № 32 (4). P. 1096.

${ }^{17}$ Davis K. The case for and against business assumption of social responsibilities. Academy of Management Journal. 1973. № 16. P. 313.

${ }^{18}$ Center for Ethical Business Cultures. Corporate social responsibility: Shape of a history, 1945-2005. History of Corp. Responsibility Project : Working Paper No 1, Minneapolis. MN: University of St. Thomas, 2005. P. 16.

19 Лукач I.B. Теоретичні проблеми правового регулювання корпоративних відносин в Україні : монографія. С. 94.

${ }^{20}$ Communication from the Commission to the European parliament, the council, the European economic and social committee and the committee of the regions A renewed EU strategy 2011-14 for Corporate Social Responsibility. URL: https://eur-lex.europa.eu/legalcontent/EN/TXT/PDF/?uri=CELEX:52011DC0681\&from=EN (accessed 01.06.2019). 
was legally shaped by the Directive 2014/95/EU28 amending Directive 2013/34/EU29 as regards disclosure of non-financial and diversity information by certain large undertakings and groups ${ }^{21}$. Pursuant to the Directive, large undertakings which are public-interest entities exceeding on their balance sheet dates the criterion of the average number of 500 employees during the financial year shall include in the management report a non-financial statement containing information to the extent necessary for an understanding of the undertaking's development, performance, position and impact of its activity, relating to, as a minimum, environmental, social and employee matters, respect for human rights, anti-corruption and bribery matters (Article 1 (1)).

Directive 2014/95/EU promotes the "comply or explain" principle: if a company fails to pursue policies relating to anti-bribery and corruption, environmental, or other non-financial matters, it will have to explain the reasons for such failure in its annual report. The directive instructs Member States to "ensure that adequate and effective means exist to guarantee disclosure of non-financial information..." and, to that end, that "effective national procedures are in place to enforce compliance with the obligations laid down by this Directive..."22.

In providing this information, undertakings which are subject to this Directive may rely on national frameworks, Union-based frameworks such as the Eco-Management and Audit Scheme (EMAS), or international frameworks such as the United Nations (UN) Global Compact, the Guiding Principles on Business and Human Rights implementing the UN 'Protect, Respect and Remedy' Framework, the Organisation for Economic Co-operation and Development (OECD) Guidelines for Multinational Enterprises, the International Organisation for Standardisation's ISO 26000, the International Labour Organisation's Tripartite Declaration of principles concerning multinational enterprises and social policy, the Global Reporting Initiative, or other recognised international frameworks (Preamble, para.9).

21 Directive 2014/95/EU of the European Parliament and of the Council of 22 October 2014 amending Directive 2013/34/EU as regards disclosure of non-financial and diversity information by certain large undertakings and groups (2014) OJ L330/1.

22 Kolohoida O., Lukach I., Poiedynok V. Legal Aspects of Corporate Social Responsibility in Ukraine on the Way to European Integration. Croatian Yearbook of European Law and Policy. 2017. № 13. P. 304. 
CSR is portrayed as important to the competitiveness of enterprise. The concept is meant to bring benefits in terms of risk management, cost savings, access to capital, customer relationships, human resource management, and innovation capacity. CSR, as defined, may encompass some aspects of human rights - in particular labor and social rights - but the focus of CSR has been broader and not as explicit about human rights as an end goal. CSR, in contrast, incorporates human rights, at best, as a component of a larger ethical and value-based set of decisions ${ }^{23}$.

Due to the leading role of a corporate decision-making in the CSR framework one can describe CSR as a bottom-top (bottom-up) phenomenon.

\section{Bhr: Top-Bottom}

This is where BHR provides an alternative, a focus on establishing a core obligation of companies to respect human rights wherever they operate, to do no harm and when harm is caused to provide a meaningful remedy to victims ${ }^{24}$.

BHR as a strand of legal thought has existed since the late 1970s. Its focus on the "legal" as opposed to moral or ethical considerations is not incidental. It emerged out of reaction at specific tragic cases and the subsequent attempt to compensate for the damage already done, rather than the theoretical discussion about the role of companies as bearers of positive obligations along with the states. The negative social effects of doing business have become particularly well known in connection with the activities of transnational corporations (TNC) in so-called "host countries".

The track record of human rights abuses by companies is lengthy and multi-faceted. In the 1980s, a gas leak at Union Carbide's pesticide plant in Bhopal, India, killed and injured thousands of people and highlighted how difficult it is for victims in transnational tort cases to seek a remedy from a $\mathrm{TNC}^{25}$. In the mid-1990s, companies

23 Ramasastry A. Corporate Social Responsibility Versus Business and Human Rights: Bridging the Gap Between Responsibility and Accountability. Journal of Human Rights. 2015. Vol. 14. № 2. Pp. 239-240.

${ }^{24}$ Ibid. P. 240.

25 Bhopal disaster. URL: https://en.wikipedia.org/wiki/Bhopal_disaster (accessed 01.06.2019). 
predominantly in the extractive sector started to be called out publicly, for example, for their role in human rights violations committed by hired security forces or for their collusion with repressive governments in violently putting down demonstrations and protests. Examples include Enron in India, Unocal in Burma, ExxonMobil in Indonesia, and perhaps most prominently, Shell in Nigeria for its role in the execution of playwright and activist Ken Saro-Wiwa and the assault by the Abacha government on the fundamental rights especially of the Ogoni people in the Niger Delta ${ }^{26}$.

At the same time claims were brought against Swiss banks, European insurers, and German corporations with respect to their involvement in World War II. Numerous abuses were found also in apparel and footwear industry. Nike and Wal-Mart, for example, were revealed to have child labor in their supply chains. Nike was also reported to use factories in Southeast Asia with very poor health and safety conditions, as well as the GAP. In the tech sector, Yahoo and other Internet giants were linked to human rights abuses in China. Yahoo, in particular, was sued under the Alien Tort Statute when it was revealed that it had handed over subscriber information to the Chinese government, which led to the imprisonment and torture of prominent Chinese dissidents ${ }^{27}$.

What was new about the emerging debate was not per se the connection of human rights and business, but rather that its concern with human rights started to reach decisively beyond labor and employment issues, which significantly differed it from the CSR debate.

The modern legal articulation of the BHR concept are the UN Guiding Principles on Business and Human Rights (UNGPs), unanimously adopted by the UN Human Rights Council in $2011^{28}$. The man behind the UNGPs was Professor John Ruggie, serving as the Special Representative to the UN Secretary General on Business and Human Rights. It's worth mentioning that UNGPs make no reference to CSR.

${ }^{26}$ Wettstein F. CSR and the debate on business and human rights. Business Ethics Quarterly. 2012. № 22(4). P. 745.

27 Ramasastry A. Corporate Social Responsibility Versus Business and Human Rights: Bridging the Gap Between Responsibility and Accountability. P. 242.

28 United Nations Guiding Principles on Business and Human Rights. URL: https://www.ohchr.org/Documents/Publications/GuidingPrinciplesBusinessHR_EN.pdf (дата звернення 28.05.2019). 
UNGPs have three pillars representing their key ideas:

Pillar $I$ is the state duty to protect against human rights abuses by third parties, including business,

Pillar II is the corporate responsibility to respect human rights, and

Pillar III is access to remedy, calling for states and the private sector to provide victims with access to effective remedies, judicial and nonjudicial.

The tripartite framework is described by the motto "Protect, Respect and Remedy".

Traditionally, human rights obligations are addressed to states and have been intended principally to regulate the relations between individuals and the state. The state not only bears a duty to respect the human rights of the individuals on its territory, but also has a duty to ensure that private actors, including companies, do not violate those rights. This has been explicitly included in the 1966 International Covenant on Civil and Political Rights (ICCPR), which gives states the obligation "to respect and to ensure to all individuals within its territory and subject to its jurisdiction the rights recognized in the present Covenant" 29 .

In this vein, Principle 1 of the UNGPs obliges states to protect against human rights abuse within their territory and/or jurisdiction by third parties, including business enterprises. This requires taking appropriate steps to prevent, investigate, punish and redress such abuse through effective policies, legislation, regulations and adjudication.

Moreover, the Commentary to Principle 3 (General state and Regulatory Functions) points out that States should not assume that businesses invariably prefer, or benefit from, State inaction, and they should consider a smart mix of measures - national and international, mandatory and voluntary - to foster business respect for human rights.

The acknowledgement of the leading role of the state as a regulator and enforcer of laws is a fundamental feature of BHR and at the same time clearly distinguishes this concept from CSR. BHR focuses primarily on the role of states in supervising their corporate citizens, and not merely encouraging them - both inside and outside the home country.

${ }^{29} 1966$ International Covenant on Civil and Political Rights, 999 UNTS 17, Article 2. 
Pillar II of the UNGPs, concerned with corporate responsibility to respect human rights, refers to "internationally recognized human rights - understood, at a minimum, as those expressed in the International Bill of Human Rights and the principles concerning fundamental rights set out in the International Labor Organization" (Principle 12). The Commentary to Principle 12 goes in more detail: "An authoritative list of the core internationally recognized human rights is contained in the International Bill of Human Rights (consisting of the Universal Declaration of Human Rights and the main instruments through which it has been codified: the International Covenant on Civil and Political Rights and the International Covenant on Economic, Social and Cultural Rights), coupled with the principles concerning fundamental rights in the eight ILO core conventions as set out in the Declaration on Fundamental Principles and Rights at Work. These are the benchmarks against which other social actors assess the human rights impacts of business enterprises".

Pillar II is non-binding, as it merely calls for companies to respect human rights via risk assessment in the form of an ongoing process referred to as human rights due diligence. This process is not meant to be a one-time look at company operations but a continuous process of identifying risks of companies that may cause or contribute to adverse human rights impacts. Due diligence helps them to identify and prevent harms but, more importantly, to provide access to remedy. Human Rights due diligence provides companies with a process by which to assess corporate conduct against a universal set of rights. Companies are meant to engage in an ongoing and iterative process to assess conduct against a common set of rights. Human rights due diligence is subject to critic, however, as some see it as too weak of a measure to hold companies accountable for their wrongdoings ${ }^{30}$.

Finally, Pillar III calls for states to provide access to judicial remedy and for companies and states to also provide for nonjudicial mechanisms in case of business-related human rights abuse. The Commentary to Principle 25 points out that "unless States take appropriate steps to investigate, punish and redress business- related human rights abuses

${ }^{30}$ Ramasastry A. Corporate Social Responsibility Versus Business and Human Rights: Bridging the Gap Between Responsibility and Accountability. P. 247. 
when they do occur, the State duty to protect can be rendered weak or even meaningless".

The essence of the UNGPs as a legal articulation of BHR concept can be summarized as follows. Firstly, States bear the duty to actively protect human rights; not per se responsible for human rights abuse by private actors, they are obliged to foster corporate respect. Secondly, companies are called not to just comply with law or even behave in a socially responsible way, but are asked to perform human rights due diligence. Finally, when companies have contributed to or caused harm, the UNGPs ensure that victims have access to a proper remedy of a judicial or non-judicial character.

Due to the leading role of the state in the BHR framework one can describe BHR as a top-bottom (top-down) phenomenon.

\section{A Common Course and Ukrainian Dimension}

The main direction of criticism of the UNGPs is that their developers focused the corporate involvement in ensuring human rights on the negative obligation to refrain from human rights abuse rather than on the positive obligation to promote the realization of human rights, while all positive obligations in this vein belongs exclusively to the state. In the meantime, states often cope poorly with the role of major enforcer and protector, and companies can also play an important role in this regard. In the modern world, companies often outperform the state in the possibilities of dominance and impact or, at least, can positively influence the state's performance of its functions.

And this is where BHR could actually borrow from CSR in terms of creating obligations or expectations that companies play a stronger role in the promotion of human rights - in positive obligations ${ }^{31}$.

On the other hand, there are indications that CSR is being redefined to encompass a limited vision of BHR. The new EU definition of CSR as "the responsibility of enterprises for their impacts on society" brings the concept much closer to BHR along with the legislative initiatives on non-financial reporting discussed above. The European Commission, in its CSR Report, notes: "Although there is no "one-size-fits-all" and for most small and medium-sized enterprises the CSR process remains informal, complying with legislation and collective agreements

\footnotetext{
${ }^{31}$ Wettstein F. CSR and the debate on business and human rights. P. 739.
} 
negotiated between social partners is the basic requirement for an enterprise to meet its social responsibility. Beyond that, enterprises should, in the Commission's view, have a process in place to integrate social, environmental, ethical human rights and consumer concerns into their business operations and core strategy in close cooperation with their stakeholders" ${ }^{32}$. It also states that governments can use regulation "to create an environment more conducive to enterprises voluntarily meeting their social responsibility" 33 . The Commission has expressly said: " ....we've introduced a smart mix of voluntary and mandatory actions to promote CSR, and implement the UN guiding principles on business and human rights (UNGPs), ${ }^{34}$.

The analysis of CSR and BHR presents some apparent synergies and complementarities between the two. Most prevalently, the wide and proactive focus of CSR contrasts with and complements the binding character of human rights obligations. A closer integration of the two debates, as Florian Wettstein argues, would allow for the formulation of an expansive and demanding conception of corporate human rights obligations. Such a conception does not stop with corporate obligations "merely" to respect human rights, but includes an extended focus on proactive company involvement in the protection and realization of human rights. In other words, the integration of the two debates provides the space within which to formulate positive human rights obligations for corporations ${ }^{35}$.

What is the level of Ukraine's involvement with CSR and BHR? According to the survey "CSR Development in Ukraine: 2010-2018", despite the fact that most companies (83\%) implement CSR, only half (52\%) of them have a social responsibility strategy (policy) and half as many own a budget for its execution (24\%). Only one third of companies have experienced increase in budget dedicated to social responsibility during last three years. Only $12 \%$ have a system of indicators to measure the efficiency of social responsibility policy, reports are prepared by $13 \%$ of companies. Though, the list of indicators provided by representatives of companies to measure the level of activity

\footnotetext{
${ }^{32}$ Communication from the Commission (n 13) para 3.

${ }^{33}$ Communication from the Commission (n 13) para 5.

${ }^{34}$ Corporate Social Responsibility \& Responsible Business Conduct. URL: https:// ec.europa.eu/growth/industry/corporate-social-responsibility (accessed 01.06.2019).

${ }^{35}$ Wettstein F. CSR and the debate on business and human rights. P. 739.
} 
dedicated to social responsibility gives grounds to affirm that Ukrainian companies are actually deprived of these indicators ${ }^{36}$. As to the figure $83 \%$, I consider it as a big overestimation attributing to a fact that companies regard as CSR things that in fact constitute basis compliance with labor law ("white" salaries, operational safety measures and so on).

The survey highlights strong dependence of the CSR policies upon state support. Hence, the concluding recommendations are focused on the state as a primary driver of the CSR development:

1. Considering the fact that CSR development in companies greatly depends on the support of the state, it would be reasonable to introduce CSR requirements for public companies, primarily.

2. The primary incentive for CSR integration in Ukraine would be introduction of mandatory non-financial disclosure in annual reports for large and public companies pursuant to the European legislation (Directive 2014/95/EU).

3. It is extremely important to introduce tax, customs benefits for the companies implementing CSR, primarily, those engaged into energy efficiency increase measures with the use of production capacities, use of renewable sources of energy, social investing into development of a region of their presence.

4. It is rather important that the government recognizes the companies implementing CSR by means of national and regional ratings, awards, etc.

5. At the national level, it would be essential for the state to develop and adopt the National strategy for corporate social responsibility which would provide the Ukrainian business with guidance and prospects for support and recognition on the part of the state.

6. At the local level, a good impetus for CSR implementation would be creation of a bank with data on region's needs for social investments, environmental projects, creation of a platform of non-government and research organizations promoting ideas of social responsibility and providing educational and consulting services on these issues ${ }^{37}$.

Drawing on Ukrainian experience, Oleksandra Kolohoida, Iryna Lukach and Valeriia Poiedynok highlight the necessity of non-financial

36 Зінченко А., Саприкіна М. Розвиток КСВ в Україні: 2010-2018. К.: Юстон, 2017. C. 25.

${ }^{37}$ Ibid. P. 50. 
reporting not only for public companies but also for other public-interest entities (i.e. big companies in general). In Ukraine, some large companies are afraid to register as a company limited by shares while the stock market is still not fully formed. For example, Nova Poshta which is the leader in the private mail delivery market employs 22,000 people, although it is a limited liability company (the LLC form in Ukraine is regulated more like that in the USA and not as in Germany), while Epicentr, the largest Ukrainian construction products supermarket network, hardly has any information on the number of employees. It is also important to fulfil provisions concerning consolidated non-financial statements in Ukraine and remember that many Ukrainian enterprises are members of large groups ${ }^{38}$.

As regards BHR, the UN Human Rights Council has encouraged all states to adopt National Action Plans (NAPs) to implement the UNGPs. Moreover, the UN Working Group on Business and Human Rights, which consists of five experts, has published detailed guidance on both the content of NAPs and the process by which they should be developed $^{39}$. To date NAPs have been developed and published by the overwhelming majority of the EU countries, the USA, South Korea, Colombia, Chile, and Georgia. Ukraine belongs to the countries that are in the process of developing the $\mathrm{NAP}^{40}$. This is a good result, in view of the fact that, apart from Georgia and Ukraine, no other country of the former USSR, nor a number of Central and Southern European countries has taken any steps in this direction.

That said, I believe that the degree of Ukraine's involvement in the global CSR and BHR discourses should be evaluated with only limited optimism. It is clear that the burden of participation in this discourse is carried out by highly specialized agencies and a narrow circle of specialists. In the meantime, the concepts of socially responsible business became capable only under condition of proper awareness of these concepts by a wide range of Ukrainian companies and their

38 Kolohoida O., Lukach I., Poiedynok V. Legal Aspects of Corporate Social Responsibility in Ukraine on the Way to European Integration. P. 302.

${ }^{39}$ Guidance on National Action Plans on Business and Human Rights, Version 1.01. URL: http://www.ohchr.org/Documents/Issues/Business/UNWG \%20NAPGuidance.pdf (accessed 01.06.2019).

40 National Action Plans on Business and Human Rights. URL: https://globalnaps.org/ (accessed 01.06.2019). 
stakeholders. This determines the special significance of the educational and promotional components. A leading role in disseminating the ideas and practices of socially responsible business can be played by courses on social responsibility at higher educational establishments and centers for professional development and advanced studies, publishing handbooks, holding public events for academia and practitioners, etc. This is primarily a public law affair but at the same time calls for a deep understanding of business motivation. It seems that the national doctrine of economic law, with its focus on compliance with public interest in doing business and its methodological pluralism, is best suited for this role. The fact that its realization requires the mastery of aspects that traditionally lay outside the economic law agenda (i.e. human rights) should be seen not as an obstacle, but as an opportunity for the enrichment and development of the economic law doctrine.

On the other side, Ukraine could actually benefit from being a novice in the fields of CSR and BHR. It is in a good position to take a fresh and unobscured view of both debates and to avoid a pitfall of a separate development or even competition between them instead of mutually beneficial integration. Unfortunately, the danger of such separation is quite real as each debate is conducted by its "own" specialized team which may not be motivated to engage in broader discourse. Here, again, a national legal doctrine can provide the necessary theoretical foundation as well as the interface of interaction in making a comprehensive portrait of a socially responsible businessman.

\section{CONSLUSIONS}

Corporate Social Responsibility and Business \& Human Rights are contextually and conceptually different courses of global legal thought, which, however, ultimately serve the common goal of ensuring socially responsible business behavior. While CSR focuses on socially responsible behavior in the broad sense, driven by the will of the companies themselves who see the way to increasing their own competitiveness in this behavior, BHR focuses on specific legal obligations of companies in the field of human rights and remedying the harm caused. BHR positions itself as a response to a "legally vague" CSR and its potential failure, but suffers from its own methodological deficiency as is largely neglects the positive role that companies can play in protecting and promoting human rights. 
Although the United Nations Guiding Principles on Business and Human Rights (UNGPs) as a legal articulation of BHR don't refer to CRS, Directive 2014/95/EU amending Directive 2013/34/EU as regards disclosure of non-financial and diversity information by certain large undertakings and groups does mention UNGPs among the frameworks which may be used by companies when complying their non-financial reports. A new definition of CSR given by European Commission also suggests the increased willingness to include human rights considerations into the CSR agenda. Surely, there is a potential of a closer integration of the two concepts which would allow for the formulation of a comprehensive conception of corporate human rights obligations. Such a conception should combine an extended focus on proactive company involvement in the protection and realization of human rights with certain legally binding obligations.

Ukraine shows some level of involvement into the global CSR and BHR discourses but further steps should be taken both to raise public awareness thereof and to give those discourses a national legal shape. In the field of CSR, the primary step would be introduction of mandatory non-financial disclosure in annual reports for large and public companies pursuant to Directive 2014/95/EU. In the field of BHR, one awaits for the publication of a National Action Plan. A pitfall to be avoided is, however, is a separate development of two discourses or even competition between them instead of mutually beneficial integration.

\section{SUMMARY}

The article deals with Corporate Social Responsibility (CSR) and Business and Human Rights (BHR) as closely related courses of global legal academic thought focused on companies engaging in responsible and socially beneficial activities. The author seeks to identify their common and distinctive features, to outline the perspective ways of their integration and to highlight their importance for the national legal doctrine in Ukraine.

In the CSR framework, the emphasis is on corporate decisionmaking, rather than on state regulation of companies' activities or their legal responsibility. CSR is considered to be a factor in the competitiveness of the enterprise. Instead, the BPL assesses corporate behavior in the light of universally accepted human rights standards enshrined in fundamental international treaties, and focuses more on 
holding companies accountable for harm caused than positively recognizing the role companies can play in promoting and protecting human rights.

The author calls for a closer integration of the two concepts which would allow for the formulation of a comprehensive conception of corporate human rights obligations combining a focus on proactive company involvement in the protection and realization of human rights with certain legally binding obligations.

Ukraine shows some level of involvement into the global CSR and BHR discourses but further steps should be taken both to raise public awareness thereof and to give those discourses a national legal shape, namely, the introduction of mandatory non-financial disclosure in annual reports for large and public companies pursuant to Directive 2014/95/EU in the field of CSR and the publication of a National Action Plan in the field of BHR. A pitfall to be avoided is, however, is a separate development of two discourses or even competition between them instead of mutually beneficial integration. The author also highlights the potential of a national economic law doctrine in addressing the debate.

Key words: corporate social responsibility; business \& human rights; United Nations Guiding Principles on Business \& Human rights; Protect, Respect, Remedy; positive responsibility; negative responsibility.

\section{REFERENCES}

1. 1966 International Covenant on Civil and Political Rights, 999 UNTS 17.

2. Bhopal disaster. URL: https://en.wikipedia.org/wiki/Bhopal_ disaster (accessed 01.06.2019).

3. Bilchitz D. The Ruggie Framework: An Adequate Rubric for Corporate Human Rights Obligations? 2009. URL: http://papers.ssrn.com/sol3/papers.cfm?abstract id=1394367 (accessed 01.06.2019).

4. Bowen H. Social Responsibilities of the Businessman. Iowa City: University of Iowa Press, 1959/2013, p. 6.

5. Buhmann, K. Corporate social responsibility: What role for law? Some aspects of law and CSR. Corporate Governance. 2006. № 6(2). Pp. 188-20. 
6. Carroll Archie B. Corporate social responsibility: Evolution of a definitional construct. Business \& Society. 1999. № 38(3). Pp. 268-295.

7. Center for Ethical Business Cultures. Corporate social responsibility: Shape of a history, 1945-2005. History of Corp. Responsibility Project : Working Paper No 1, Minneapolis. MN: University of St. Thomas, 2005. P. 16.

8. Communication from the Commission to the European parliament, the council, the European economic and social committee and the committee of the regions A renewed EU strategy 2011-14 for Corporate Social Responsibility. URL: https://eur-lex.europa.eu/ legal-content/EN/TXT/PDF/?uri=CELEX:52011DC0681\&from=EN (accessed 01.06.2019).

9. Corporate social responsibility - CSR-UA URL: http://sr-ua.info/csr-ukraine (accessed 01.06.2019).

10. Corporate Social Responsibility \& Responsible Business Conduct. URL: https://ec.europa.eu/growth/industry/corporate-socialresponsibility (accessed 01.06.2019).

11. Corporate social responsibility: From Wikipedia, the free encyclopedia URL: https://en.wikipedia.org/wiki/Corporate_social_ responsibility (accessed 01.06.2019).

12. David D. Business Responsibilities in an Uncertain World. Harvard Business Review. 1949. № 27 (3 Suppl.). Pp. 1-8.

13. Davis K. The case for and against business assumption of social responsibilities. Academy of Management Journal. 1973. № 16. P. 313.

14. Dempsey B. The Roots of Business Responsibility. Harvard Business Review. 1949. № 27 (4). Pp. 393-404.

15. Directive 2014/95/EU of the European Parliament and of the Council of 22 October 2014 amending Directive 2013/34/EU as regards disclosure of non-financial and diversity information by certain large undertakings and groups (2014) OJ L330/1.

16. Friedman M. Capitalism and freedom. Chicago: University of Chicago Press, 1962, p. 133.

17. Guidance on National Action Plans on Business and Human Rights, Version 1.01. URL: http://www.ohchr.org/Documents/Issues/ Business/UNWG \%20NAPGuidance.pdf (accessed 01.06.2019). 
18. Heald M. The Social Responsibilities of Business: Company and Community 1900-1960. Livingston : Transaction Publishers, 1970. Pp. 118-119.

19. History of Corporate Responsibility Project. Corporate social responsibility: The shape of a history, 1945-2004 : Center for Ethical Cultures Working Paper, 2005. URL: http://www.cebcglobal.org/ index.php?/knowledge/history-working-papers/ (accessed 01.06.2019).

20. International Council on Human Rights Policy (ICHRP). Beyond Voluntarism: Human Rights and the Developing International Legal Obligations of Companies. Geneva: ICHRP, 2002. URL: http://ssrn.com/abstract=1553201 (accessed 01.06.2019).

21. Kolohoida O., Lukach I., Poiedynok V. Legal Aspects of Corporate Social Responsibility in Ukraine on the Way to European Integration. Croatian Yearbook of European Law and Policy. 2017. № 13. Pp. 291-312.

22. National Action Plans on Business and Human Rights URL: https://globalnaps.org/ (accessed 01.06.2019).

23. Ramasastry A. Corporate Social Responsibility Versus Business and Human Rights: Bridging the Gap Between Responsibility and Accountability. Journal of Human Rights. 2015. Vol. 14. № 2. Pp. 237-59.

24. Scherer A., Palazzo G. Toward a Political Conception of Corporate Responsibility: Business and Society Seen from a Habermasian Perspective. Academy of Management Review. 2007. № 32 (4). Pp. 1096-1120.

25. United Nations Guiding Principles on Business and Human Rights. URL: https://www.ohchr.org/Documents/Publications/Guiding PrinciplesBusinessHR_EN.pdf (accessed 01.06.2019).

26. Wettstein F. CSR and the debate on business and human rights. Business Ethics Quarterly. 2012. № 22 (4). Pp. 739-770.

27. В Інституті економіко-правових досліджень НАН України відбувся міжнародний науково-практичний семінар «Зміцнення засад у сфері бізнесу і прав людини: драйвери для України» URL: http://www.nas.gov.ua/EN/Messages/News/Pages/View.aspx?MessageI $\mathrm{D}=4408$ (accessed 01.06.2019).

28. Зінченко А., Саприкіна М. Розвиток КСВ в Україні: 20102018. К.: Юстон, 2017. 
29. Лукач І.В. Законодавче закріплення нефінансового звіту в контексті Угоди про асоціацію. Право Украӥни. 2018. № 6. C. $143-153$.

30. Лукач I.В. Теоретичні проблеми правового регулювання корпоративних відносин в Україні : монографія. К: Ліра-К, 2015.

Information about the author: Poiedynok V. V. Doctor of Law, Professor at the Economic Law Department, National Taras Shevchenko University of Kyiv 60, Volodymyrska str., Kyiv, Ukraine 